\title{
THE RELATIONSHIP BETWEEN KNOWLEDGE MANAGEMENT, LEADERSHIP STYLE, AND WORK MOTIVATION: EVIDENCE FROM AN ISLAMIC BOARDING SCHOOL
}

\author{
Soeprayitno* \\ Universitas Sebelas Maret
}

\begin{abstract}
This study empirically examines the relationship between leadership, knowledge management, and teacher motivation by studying a boarding school. Specifically, this research tests whether leadership style has a mediating effect on the relationship between knowledge management and motivation. Based on the literature review, a theoretical framework for this study is established. A survey was employed to gather information from the teachers of a boarding school located in Solo city, Indonesia. This study employs SEM-PLS to estimate the empirical model. Knowledge management is found to have insignificant effect on leadership style. However, knowledge management and leadership are positively associated with teacher motivation. This research extends the literature on knowledge management by linking with teacher motivation and leadership style. The use of Islamic leadership style may also contribute to the existing literature.
\end{abstract}

Keywords: Knowledge management; Leadership; Motivation; Boarding school.

Received: 18 February 2020

Accepted: 16 June 2020

\section{INTRODUCTION}

Appropriate leadership style has been an important issue for organization in this today's globalized era which leads to extensive studies in this particular field (Birasnav et al., 2013). Some studies have introduced different types of innovative leadership styles such as transformational leadership (developed by Burns, 1978; Bass and Avolio et al, 1999 ${ }^{1}$ ) and is the most active construct in the literature), wise (phronetic) leadership (e.g. Ding et al., 2019), and some local-based leadership style such as Hasthabrata leadership (e.g. Suyono et al., 2017). Those innovative leadership styles are basically presented to change the old leadership style such as transactional leadership. The other concept of leadership which emerges in the literature is the Islamic leadership (e.g. Ahmad and Ogunsola, 2011; Faris and Perry, 2011; Egel and Fry, 2017). Islamic organization leadership is the same to conventional leadership except in its religious, moral, and human roots (Ahmad and Ogunsola, 2011).

In this present paper, I empirically examine the impact of knowledge management process in an organization on the appropriateness of the implementation of leadership style, more particular Islamic leadership style in the context of boarding school. Some previous empirical studies have

\footnotetext{
- Soeprayitno.trisakti@gmail.com

${ }^{1}$ For the recent literature review on transformational leadership, please see the paper of Siangchokyoo et al. (2020)
} 
investigated the relationship between leadership and knowledge management, however most of them look at the effect of leadership style on the implementation of knowledge management. For instance, Birasnav (2014) documents that transformational leadership has a positive and strong impact on knowledge management process and organization performance. Ding et al. (2019) find that knowledge management mediate the link between wise leadership and organization innovation performance. This paper, on the different way, examines the effect of knowledge management on the leadership style.

Furthermore, in this study, the ultimate outcome on the interaction between knowledge management and leadership style is work motivation. I argue here that work motivation should be improved with the appropriate implementation of leadership style which is affected by the extent to which knowledge management is applied. Moreover, Osman and Warner (2020) explain that teachers' motivation to apply professional development is an essential outcome of teacher professional development

This study takes different perspective and contribute to the existing literature in the following ways. First, as explained earlier, previous studies (e.g. Birasnav, 2014; Donate and de Pablo, 2015) focus on the effect of leadership style on knowledge management process, this study, however, look at differently. I hypothesize that knowledge management, on the other hand, due to the specific context of boarding school, may trigger the teachers to implement the Islamic leadership style. Second, I also examine the mediating role of leadership style on the relationship between knowledge management and work motivation. Arguably, knowledge management leads to the implementation of Islamic leadership style, which subsequently improve the teachers' work motivation. Third, this research was done in a boarding school in Indonesia which has unique characteristics especially in the implementation of Islamic principles in the education. Therefore, this study could provide an insight on how to improve employee motivation through effective knowledge management and Islamic-based leadership styles.

\section{LITERATURE REVIEW}

\subsection{Knowledge Management}

Knowledge management has been widely considered to be a unique and important resource for a business organization to deliver product/ services (Birasnav, 2014; Friedrich et al., 2020). Therefore, over the last few decades, knowledge management has paid more attention by scholars in the organization behavior. Basically knowledge-based view (KBV) is derived from the resourcebased view (RBV) in which organization strategy and eventually organization performance is determined by the extent to which an organization has substantial resources that are rare and difficult to imitate. Under the KBV, knowledge is the main strategic resource of organizations to create value (Zack et al., 2009; Donate and de Pablo, 2015).

Formally, knowledge management is defined as a set of activities, initiatives, and strategies that organizations exploit to generate, store, transfer, and implement knowledge for the enhancement of organizational performance (Zack et al., 2009). Knowledge management is widely believed to be a source of competitive advantage in the recent information economy era. Some empirical studies have investigated the impact of knowledge management process in organizations on the 
organization performance. Most of them find significant contribution of knowledge management on overall performance (e.g. Birasnav, 2014), innovation performance (e.g. Birasnav et al., 2013; Ding et al., 2019).

Some other papers look at the determinants of success in the implementation of knowledge management process. Some of them point out that leadership play important role (e.g. Birasnav, 2014; Donate and de Pablo, 2015; Naqshbandi and Jasimuddin, 2018; Ding et al., 2019). In general, they contend that to implement knowledge management appropriately, it needs an encouraging leadership style which is mostly found in the transformational leadership or wise leadership.

\subsection{Leadership Style}

There have been a number of innovative leadership concepts introduced in the organization behavior literature. The most famous one is transformational leadership in which leaders, who have strong vision, put more efforts to help improve the employee's self-confidence by realizing their potential, communicating organization vision and mission that require engagement of the employees and working with the employees to identify their needs and collaboratively work to fulfill those needs (Peterson et al., 2009). This concept is basically to encourage employees to have more engagement with the organization which is expected to improve the individual and organization performance.

The other concept of leadership style is based on local wisdom such as wise (phronetic) leadership (Nonaka \& Takeuchi, 2011; Ding et al., 2019). Basically, they explain that wise leadership is to enhance the collective consciousness to engage in the organization. Therefore, it should not only be limited at the top management but also at the middle level leaders. Other local wisdom-based leaderships are also found in the literature, for instance: Hasthabrata leadership, Javanese leadership concept (Suyono et al., 2017).

This present study concerns on the Islamic leadership concept. Faris and Perry (2011) mention that there is a challenge to reconstitute the Islamic leadership particularly in the context of organization. Egel and Fry (2017) introduce a model of spiritual and Islamic leadership that more appropriate for Islamic organizations and organizations employing Muslim workers. Ahmad and Ogunsola (2011) explain that Islamic leadership principles consist of faith and belief in God, knowledge and wisdom, courage and determination, mutual consultation, morality and piety, patience, express gratitude, and endurance.

\subsection{Work Motivation}

There are two strands of literature on work (employee) motivation. On the one side, some previous studies empirically examine the determinants or predictors of work motivation mostly using selfdetermination theory (SDT). For instance, Lam and Gurland (2008) find that autonomy orientation is a strong prediction of work motivation, the greater the autonomy in the job place, the higher the work motivation of the employees. Similar result is found the study of Arshadi (2010). Taguchi (2015) explain that there a set of factors forming work motivation including income, employee evaluation, establishment, growth, human relationships, working condition, work, work-life balance and workplace. Björklund et al. (2013) find that change in the work motivation is associated with mental well-being. Similarly, Fook et el. (2011) reveal that psychological 
empowerment positively associated with work motivation. Saether (2019), by focusing on employees in the high-tech R\&D, documents that wok motivation can be explained by selfdetermined motivation, person-organization fit, organization support of creativity, and pay justice. More recently, Kanat-Maymon et al. (2020) argue that leadership play important role in explaining work motivation of employees.

The other area of literature discusses on the implications of work motivation. Lam and Gurland (2008) explain that the direct impact of work motivation could be job satisfaction and identification commitment. Hsu (2013) documents that the lower the work motivation, the higher the job burnout will be. The recent paper of Kanat-Maymon et al. (2020) finds that leadership is not only antecedent of work motivation, but it could also be the consequence of work motivation.

\section{RESEARCH METHOD}

As specified above, this research focuses on investigating the triangle relationship between knowledge management, leadership and motivation. First, I test the impact of knowledge management on leadership style. Second, the direct effect of knowledge management on work motivation. Lastly, I explore the mediating role of leadership by testing the effect of leadership on work motivation. This research is a cross-sectional study where information was collected once using questionnaire. The respondents are teachers in Pesantren Assalam (Assalam Islamic Boarding School) located Solo city, Indonesia. According to the report of Bidang Sumberdaya Insani-PPMI (Human Resource Department) of Assalam Boarding School, there are 189 active teachers in this school. A combination between cluster sampling and convenience sampling was employed as there are different types of teachers in this boarding school including permanent teachers and non-permanent teachers.

\subsection{Variable and Measurement}

The measurement scale items for each construct are adapted from the previous studies.

\subsubsection{Leadership Style}

Leadership Style measurement is based on the Islamic leadership style which consists of six dimensions: Amanah (trustworthy), Fair, Brave, Fathonah (smart/wise), Visionary, and Participative. A five-point Likert scale is used, respondents were requested to assess the leadership based on Islamic leadership principles.

\subsubsection{Knowledge Management}

Knowledge Management measurements are adapted from Yeo (2003). The items were measured using five-point Likert scales. There are three dimensions of knowledge management which are individual learning, individual group and individual institution 


\subsubsection{Work Motivation}

Work (employee) motivation was attuned from various studies such as those employed by Yeo (2003). With respect to items of organizational culture, Employee Motivation also use a five-point Likert scale. There are three aspects representing the work motivation which are rewards, responsible and work quality.

\subsubsection{Data Analysis}

This study employs SPSS version 22 and PLS-SEM 3.28 to estimate the empirical model. Ethical consent was conceded by the Assalam Boarding School ethical committee, which approves the research instruments that are used to collect the data.

\section{RESULTS}

Statistical analysis to detect errors in all constructs was applied. Variables and model are assessed for validity, collinearity, significance, and relevance of indicators by checking the outer weights and outer loadings of the formative construct in the PLS path model. As a rule of thumb, I necessitate to take in a VIF score of 5 or lower (i.e., the tolerance level of 0.2 or higher) to avoid collinearity problems. The VIF value is $<5$ for all indicators.

\subsection{Demographics of Respondents}

Our samples are permanent teachers and non-permanent teachers (temporary teachers, supporting teachers, contract-based teachers, and service teachers). The total number of teachers in the Assalam boarding school is 189 teachers, however, finally only 144 teachers filled the questionnaire. Nevertheless, the final samples represent the types of teachers in the Assalam boarding school.

\subsection{Descriptive Analysis}

Table 1: Descriptive Statistics

\begin{tabular}{|c|c|c|}
\hline Variable & Dimension & Mean \\
\hline \multirow[t]{3}{*}{ Knowledge Management } & Individual Learning & 3.57 \\
\hline & Individual Group & 3.16 \\
\hline & Individual Institution & 3.02 \\
\hline \multirow[t]{6}{*}{ Leadership Style } & Amanah (trustworthy) & 3.57 \\
\hline & Fair & 3.16 \\
\hline & Brave & 3.02 \\
\hline & Fathonah (smart/wise) & 3.57 \\
\hline & Visionary & 3.16 \\
\hline & Participative & 3.02 \\
\hline \multirow[t]{3}{*}{ Motivation } & Rewards & 3.57 \\
\hline & Responsible & 3.16 \\
\hline & Work Quality & 3.02 \\
\hline
\end{tabular}


The descriptive statistics (mean for each dimension of all variables) is presented in Table 1.

\subsection{The Measurement Model: "Outer Model"}

The research model is analyzed using PLS Structural Equation Modelling (SEM), specifically through SmartPLS 3.2 both for the main and mediating model. A PLS model analysis is presented using a two-step technique, the first step is to evaluate the measurement model (validity and reliability of the measures), and the second step is the structural model examination. Following Hair et al. (2017), a bootstrapping method was used to determine the path coefficients significance and the loadings.

As indicated by Hair et al. (2012), in evaluating the measurement model, convergent validity is tested via the factor loadings, Composite Reliability (CR), and Average Variance Extracted (AVE). As shown in Table 3, the factor loadings of all items and the reliability of the indicator all exceeded 0.7 (Hulland, 1999). As for the alpha coefficients, the cut-off values for CRs and AVEs respectively are at 0.7 and 0.5 and were all surpassed (Hair et al., 2017). Therefore, the results of the outer model confirmed that all the measurements loaded are greater on their hypothesized constructs than on other constructs; all values for AVE latent factors were higher than the cutoff value for loadings at 0.5 , thus confirming the convergent validity. This study uses $\mathrm{CR}$ in the reliability test rather than Cronbach Alpha (CA) because the Cronbach Alpha has been criticized for its lower bound value, which underestimates the true reliability.

Discriminant validity was evaluated by computing the AVE square root for every factor. Discriminant validity was achieved when AVE square root is higher than the association among the factors in the model (Hair et al., 2017). Generally, the reflective constructs in bold are all higher than the correlations of these constructs with other latent variables in the path model, therefore indicating all constructs are valid measures of unique concepts.

Table 2: Outer Loading

\begin{tabular}{lccc}
\hline \hline & Cronbach's Alpha & $\begin{array}{c}\text { Composite } \\
\text { Reliability }\end{array}$ & Average Variance Extracted (AVE) \\
\hline Knowledge Management & 0.898 & 0.916 & 0.580 \\
Leadership Style & 0.984 & 0.984 & 0.600 \\
Teacher Motivation & 0.905 & 0.921 & 0.541 \\
\hline \hline
\end{tabular}

Table 2 shows that the findings of the measurement model that were statistically acceptable in terms of reliability, convergent validity, and discriminant validity. The findings provide empirical evidence for the suggested concepts of knowledge management, leadership, and motivation as a valid and reliable instrument. 


\subsection{Evaluation of The Structural "Inner" Model}

Table 3: R Square Inner Model

\begin{tabular}{lcc}
\hline \hline & R Square & R Square Adjusted \\
\hline Leadership Style & 0.013 & 0.006 \\
Teacher Motivation & 0.376 & 0.367 \\
\hline \hline
\end{tabular}

The next procedure in PLS-SEM is to evaluate the structural model, to establish the validity and reliability of the dimension archetypal. The most crucial standard for structural model assessment is $\mathrm{R}^{2}$, as the target of the prediction-oriented, PLS-SEM approach is to explain the variance of endogenous latent variables and thus $\mathrm{R}^{2}$ values of the main target constructs have to be high (Hair et al., 2017); an $\mathrm{R}^{2}$ value for the endogenous latent variables in the structural model of 0.75 is substantial, 0.50 is moderate, and 0.25 is weak. The $\mathrm{R}^{2}$ was established as $0.075,0.108$, and 0.227 based on the outcomes of PLS algorithm estimation, confirming that Motivation is in the moderate range. The $\mathrm{R}^{2}$ value for leadership style variance in knowledge management is clarified via knowledge management, although in the weak range.

Table 4: Hypothesis Testing

\begin{tabular}{lccc}
\hline \hline Knowledge Management $\rightarrow$ Leadership Style & 0.113 & 0.169 & Decision \\
Knowledge Management $\rightarrow$ Teacher Motivation & 0.384 & 0.000 & $\begin{array}{c}\text { Positive } \\
\text { Significant } \\
\text { Positive }\end{array}$ \\
Leadership Style $\rightarrow$ Teacher Motivation & 0.436 & 0.000 & Significant \\
\hline \hline
\end{tabular}

The final step in a structural model is to detect the strength of the association between independent and dependent variables, this was calculated through testing the path coefficients. This research utilized a bootstrap re-sampling technique to estimate standard errors and t-statistics. The path coefficients and bootstrapping results were illustrated in Table 4 .

The results reveal that knowledge management has no significant effect on leadership style. However, knowledge management has a positive and significant influence on teacher motivation. Moreover, leadership is positively associated with teacher motivation. These results mean that there is no mediating role of leadership in the relationship between knowledge management and work motivation.

The findings imply that knowledge management could be a tool to motivate teachers in the boarding school. It confirms the previous studies (e.g. Taguchi, 2015) revealing that work motivation is formed by a number of factors including working condition. The strong the knowledge management process in an organization reflects the working condition. In turn, it will psychologically empower the employees (Fook et el., 2011). Knowledge management is associated with the job autonomy in which knowledge management requires a greater autonomy in most 
aspects in the organization. Therefore, employees should be more motivated as a result of the job autonomy (Lam \& Gurland 2008; Arshadi, 2010).

The other implication is that teacher motivation is strongly affected by the extent to which Islamic leadership is applied. The greater the implementation of Islamic leadership style, the higher the teacher motivation. This is in line with the previous study such as Kanat-Maymon et al. (2020). Perceived encouraging leadership could lead to more motivated employees.

\section{CONCLUSION}

This research empirically examines the relationship between leadership, knowledge management, and teacher motivation by studying a boarding school. Specifically, it tests whether leadership style has a mediating effect on the relationship between knowledge management and motivation. Based on the literature review, a theoretical framework for this study is established. A survey was employed to gather information from the teachers of a boarding school located in Solo city, Indonesia. I employ SEM-PLS to estimate the empirical model being tested. Knowledge management is found to have insignificant effect on leadership style. However, knowledge management and leadership are positively associated with teacher motivation. However, there is no evidence that leadership play role in mediating the relationship between knowledge management and work motivation.

This research extends the literature on knowledge management by linking it with teacher motivation and leadership style. The use of Islamic leadership style may also contribute to the existing literature. Practically, this study implies that employee motivation could be bolstered using both strong leadership and better implementation of knowledge management.

\section{REFERENCES}

Ahmad, K., \& Ogunsola, O. K. (2011). An empirical assessment of Islamic leadership principles. International Journal of Commerce and Management, 21(3), 291-318.

Arshadi, N. (2010). Basic need satisfaction, work motivation, and job performance in an industrial company in Iran. Procedia Social and Behavioral Sciences, 5, 1267-1272.

Avolio, B. J., Bass, B. M., \& Jung, D. I. (1999). Re-examining the components of transformational and transactional leadership using the multi-factor leadership questionnaire. Journal of Occupational and Organizational Psychology, 72(4), 441-462.

Birasnav, M. (2014). Knowledge management and organizational performance in the service industry: The role of transformational leadership beyond the effects of transactional leadership. Journal of Business Research, 67(8), 1622-1629

Birasnav, M., Albufalasa, M., \& Bader, Y. (2013). The role of transformational leadership and knowledge management processes on predicting product and process innovation: An empirical study developed in Kingdom of Bahrain. Tékhne, 11(2), 64-75.

Björklund, C., Jensen, I., Lohela-Karlsson, M. (2013). Is a change in work motivation related to a change in mental well-being? Journal of Vocational Behavior, 83, 571-580

Burns, J. M. (1978). Leadership. New York: Harper \& Row. 
Ding, W., Choi, E., \& Aoyama, A. (2019). Relational study of wise (phronetic) leadership, knowledge management capability, and innovation performance. Asia Pacific Management Review, 24, 310-317

Donate, M. J., \& Sánchez de Pablo, J. D. (2015). The role of knowledge-oriented leadership in knowledge management practices and innovation. Journal of Business Research, 68: 360-370.

Egel, E., Fry, L. W. (2016). Spiritual leadership as a model for Islamic leadership. Public Integrity, 19(1), 77-95.

Faris, N., \& Parry, K. (2011). Islamic organizational leadership within a western society: The problematic role of external context. Leadership Quarterly, 22(1), 132-151.

Fook, C. Y., Brinten, L., Sidhu, G. K., Fooi, F. S. (2011). Relationships between psychological empowerment with work motivation and withdrawal intention among secondary school principals in Malaysia. Procedia Social and Behavioral Sciences, 15, 2907-2911.

Friedrich, J., Becker, M., Kramer, F., Wirth, M., \& Schneider, M. (2020). Incentive design and gamification for knowledge management. Journal of Business Research, 106, 341-352.

Hair, J. F., Sarstedt M., Pieper T. M, Ringle, C. M. (2012) The use of partial least squares structural equation modelling in strategic management research: A review of past practices and recommendations for future applications. Long Range Planning, 45(5-6), 320-340.

Hair, J. F., Hult, G. T. M, Ringle, C. M., Sarsted, M. (2017). A primer on partial least squares structural equation modelling (PLS-SEM). Thousand Oaks, CA: Sage.

Hsu, L. (2013). Work motivation, job burnout, and employment aspiration in hospitality and tourism students-An exploration using the self-determination theory. Journal of Hospitality, Leisure, Sport \& Tourism Education, 13(1), 180-189.

Kanat-Maymon, Y., Elimelech, M., \& Roth, G. (2020). Work motivations as antecedents and outcomes of leadership: Integrating self-determination theory and the full range leadership theory. European Management Journal, forthcoming.

Lam, C. F., \& Gurland, S. T. (2008). Self-determined work motivation predicts job outcomes, but what predicts self-determined work motivation? Journal of Research in Personality, 42(4), 1109-1115.

Naqshbandi, M. M., \& Jasimuddin, S. M. (2018). Knowledge-oriented Leadership and Open Innovation: Role of Knowledge Management Capability in France-based Multinationals. International Business Review, 27(3), 701-713.

Nonaka, I., \& Takeuchi, H. (2011). The big idea: The wise leader. Harvard Business Review, 89(5), $58-67$.

Osman, D. J., \& Warner, J. R. (2020). Measuring teacher motivation: The missing link between professional development and practice. Teaching and Teacher Education, 92, 103064.

Peterson, S. J., Walumbwa, F. O., Byron, K., \& Myrowitz, J. (2009). CEO positive psychological traits, transformational leadership, and firm performance in high technology start-up and established firms. Journal of Management, 35, 348-368.

Saether, E. A. (2019). Motivational antecedents to high-tech R\&D employees' innovative work behavior: Self-determined motivation, person-organization fit, organization support of creativity, and pay justice. The Journal of High Technology Management Research, 30(2), 100350.

Siangchokyoo, N., Klinger, R. L., Campion, E. D. (2020). Follower transformation as the linchpin of transformational leadership theory: A systematic review and future research agenda. The Leadership Quarterly, 31, 101341. 
Suyono, J., Troena, E.A., Rahayu, M., Noermijati. (2017). The Hasthabrata leadership in government institution: A case study in Indonesia. International Journal of Business, 22(2), 143-157.

Taguchi, Y. (2015). Factors forming work motivation in Japan. Procedia Manufacturing, 3, 717 722.

Yeo, R. (2003). Linking organisational learning to organisational performance and success: Singapore case studies. Leadership \& Organization Development Journal, 24(2), 70-83.

Zack, M., McKeen, J., \& Singh, S. (2009). Knowledge management and organizational performance: An exploratory survey. Journal of Knowledge Management, 13(6), 392409. 